\title{
ArcheoSciences
}

Revue d'archéométrie

\section{Metallurgical and Technological Investigation on Augustean Auxiliary Coins from Thraco-Moesia}

Une recherche métallurgique et technologique sur des pièces de monnaie "auxiliaires » d'Auguste provenant de la région thracomésienne

Irene Calliari, Maurizio Magrini, Rodolfo Martini, Chiara Tellini and Eugenio Vajna de Pava

\section{OpenEdition}

Electronic version

URL: https://journals.openedition.org/archeosciences/2879

DOI: 10.4000/archeosciences.2879

ISBN: 978-2-7535-1849-0

ISSN: $2104-3728$

Publisher

Presses universitaires de Rennes

Printed version

Date of publication: 30 April 2011

Number of pages: 9-18

ISBN: 978-2-7535-1847-6

ISSN: 1960-1360

\section{Electronic reference}

Irene Calliari, Maurizio Magrini, Rodolfo Martini, Chiara Tellini and Eugenio Vajna de Pava,

"Metallurgical and Technological Investigation on Augustean Auxiliary Coins from Thraco-Moesia",

ArcheoSciences [Online], 35 | 2011, Online since 30 April 2013, connection on 01 March 2022. URL:

http://journals.openedition.org/archeosciences/2879; DOI: https://doi.org/10.4000/archeosciences. 2879 


\title{
Metallurgical and Technological Investigation on Augustean Auxiliary Coins from Thraco-Moesia
}

\author{
Une recherche métallurgique et technologique sur des pièces de monnaie \\ " auxiliaires » d'Auguste provenant de la région thracomésienne
}

\author{
Irene Calliari*, Maurizio Magrini*, Rodolfo Martini**, \\ Chiara Tellini* and Eugenio Vajna de Pava***
}

\begin{abstract}
The impressive amount of Augustean coins coming from the Thraco-Moesia area (classified in numismatic terms as "Limesfalsa"), raises some juridical and technical questions as to who were the issuing authorities and to the production techniques involved. In the present investigation a representative sampling of such coins, based on metallographic and chemical analysis, was compared on the basis of metallographic and chemical analysis to some regular coins coming from the mint of Rome. The main results can be summarized as follows:

The regular Augustaan Asses are composed of almost pure $\mathrm{Cu}$, with a fine recrystallized structure, whereas a part of the "auxiliary" samples have a lower $\mathrm{Cu}$ content, with varying amounts of $\mathrm{Pb}$ and a coarser dendritic grain structure.

The Dupondii are made of brass: the "auxiliary" samples have usually a lower weight and Zn content than the regular ones, and sometimes an irregular shape.

This data may not only confirm the theory of a partly de-centralized issuing of the base metal coins, but also the hypothesis that the primary brass production occurred under the control of the central mint.

Résumé: L’impressionnante quantité de monnaies augustéennes provenant de la région Thraco-Mésienne (appelées "Limesfalsa» en numismatique pose des questions juridiques et techniques comme: quelles étaient les autorités d'émission et quelles étaient les techniques de production employées.

Dans cet étude un échantillonnage représentatif de ces monnaiesa été comparé, sur la base des analyses métallographiques et chimiques, à des monnaies régulières provenant de l'hôtel des monnaies de Rome. Les principaux résultats sont: les as augustéens courants sont composés de cuivre presque pur, avec une fine structure recristallisée, tandis qu'une part des échantillons "auxiliaires » ont une composition plus faible, avec des quantités variables de plomb et une structure de grain dendritrique plus grossière.

Les dupondii sont composés de laiton: les échantillons « auxiliaires » ont habituellement un poids et une composition en Zn plus faibles que les réguliers et quelquefois une forme irrégulière.

Ces données peuvent non seulement confirmer la théorie d'une émission partiellement décentralisée des monnaies à bas métal, mais aussi confirmer l'hypothèse que la production de laiton primaire a eu lieu sous le contrôle de l'hôtel central.
\end{abstract}

Keywords: Roman Coins, Cu alloys, coinage technology.

Mots clés : Monnaies romaines, alliages cuivreux, technologie du monnayage.

* DPCI, University of Padua, Via Marzolo 9, Padova, Italy.

** Civiche Raccolte Numismatiche, Milan, Italy.

*** Chemical Researcher, retired, Italy. 


\section{INTRODUCTION}

Following the Augustan reform, the production of Roman Imperial coins was at first located in the mint of Rome (1) and supported by various "central" mints spread around the Western part of the Empire: Emerita, Lugdunum and the Eastern part: Ephesus, Pergamum and Antiochia ad Orontem. Their production, although issued firstly for a wide regional circulation, was nevertheless considered universal currency within the Empire (2, 3, and 4).

It is well known that other local mints, the so called "provincial" ones, were located throughout the Roman Empire; they produced coins for their specific 1 territorial needs, with monetary typologies related to cities and/or regions.

Only recently the numismatic research has identified the presence of auxiliary production centres active for a coinage entirely similar to the one coming from the Rome mint. The majority were along the Rheno-Danubian limes areas. Their emissions were most likely controlled by the Legion military command.

The impressive amount of "Augustean" coins continuously coming from the Thraco-Moesic area, and until now summarily classified as "Limesfalsa", poses some juridical and technical questions about the issuing authorities, the production techniques and the kind of alloys used for each series $(5,6)$.

In several studies $(7,8)$ the chemical analysis of a lot of numismatic materials have been performed with different methods. On the contrary, only limited metallographic data are known (8) about the $\mathrm{Cu}$-based coins, so that there is a lack of information exists on the technological process used to produce coins of varying composition. The combination of chemical analysis $(9,10)$ with metallurgical investigation on cross sections results in a complete description of a coin and its production steps, from the melt alloy to the final coin shape.

The pure $\mathrm{Cu}$ can be distinguished from the $\mathrm{Cu}$-alloyed specimens by a careful visual inspection and, in addition, the struck coins differ from the cast ones, as the contours of the impressed struck designs are sharper and more defined than in the cast coins.

Unfortunately, in many cases the surface is strongly corroded and patinated; therefore the identification of an alloy is not so easy. An incontrovertible classification of a coin can only be made by inspecting its microstructure, as the difference between a cast (dendritic) and a mechanically (cold or hot) worked (crystallized) specimen is visually evident. (11). In numismatic literature, generally the production by casting is attributed to counterfeits or to local mints.
The two processes, namely cold-working followed by annealing or hot-working, will give essentially the same microstructure of worked and recrystallized grains, so it is not always possible to know if cold working and annealing have been used... However there may be other indications that have a bearing on the interpretation of the resulting structure, as proposed by Scott (11) and indicated in fig. 1 .

Since a large assortment of "Limesfalsa" coins have appeared on the market, some questions have arisen about the issuing authorities and the production techniques. Consequently, the hypothesis of a more widespread production of cast coins has been proposed, but no accurate metallurgical investigations have been reported to date.

In order to contribute to solving the above questions, a metallurgical examination of a large number of such coins (asses and dupondii dated I-III cent. AD) has been started. In the whole study the chemical composition and metallurgical microstructure of about 40 samples (Asses, Dupondii and Sestertii) have been determined. In the present paper the results concerning 19 samples are presented.

\section{Materials AND METHODS}

The examined coins are 11 Asses (regular and auxiliary), 2 regular Sestertii and 5 Dupondii; they were produced in Rome central mint and in local mints; they are classified as regular and auxiliary coins with different stylistic features.

Before the analysis all the coins were photographed on both sides. The photos of 3 representative coins (SC, A10 and D22) are reported in fig.2, the bad conservation status is evident.

The chemical analysis was performed by means of EDXRF on cleaned surfaces and by ICP-OES. The EDXRF spectrometer is a Kevel Delta 770 equipped with an Rh tube and a set of secondary targets. In the present research the tube operated at $55 \mathrm{kV}$ and the Gd secondary target was used, in order to excite all the elements from $\mathrm{Cu}$ to $\mathrm{Sn}$.

A Spectrom Genesis ICP-OES spectrometer has been used; the specimens for ICP were taken at the inner part of the coins, with special care to avoid the analysis of corroded or modified surface layers. About $50 \mathrm{mg}$ of metal were dissolved in diluted nitric acid. The solution was filtered and analyzed the ICP to determine the $\mathrm{Cu}, \mathrm{Pb}, \mathrm{Fe}, \mathrm{Ni}$, and $\mathrm{Bi}$ concentration. The attention was focused on the intentionally added elements of the alloy; the content of some impurities was calculated in view of possible evidences about the raw material origin. 


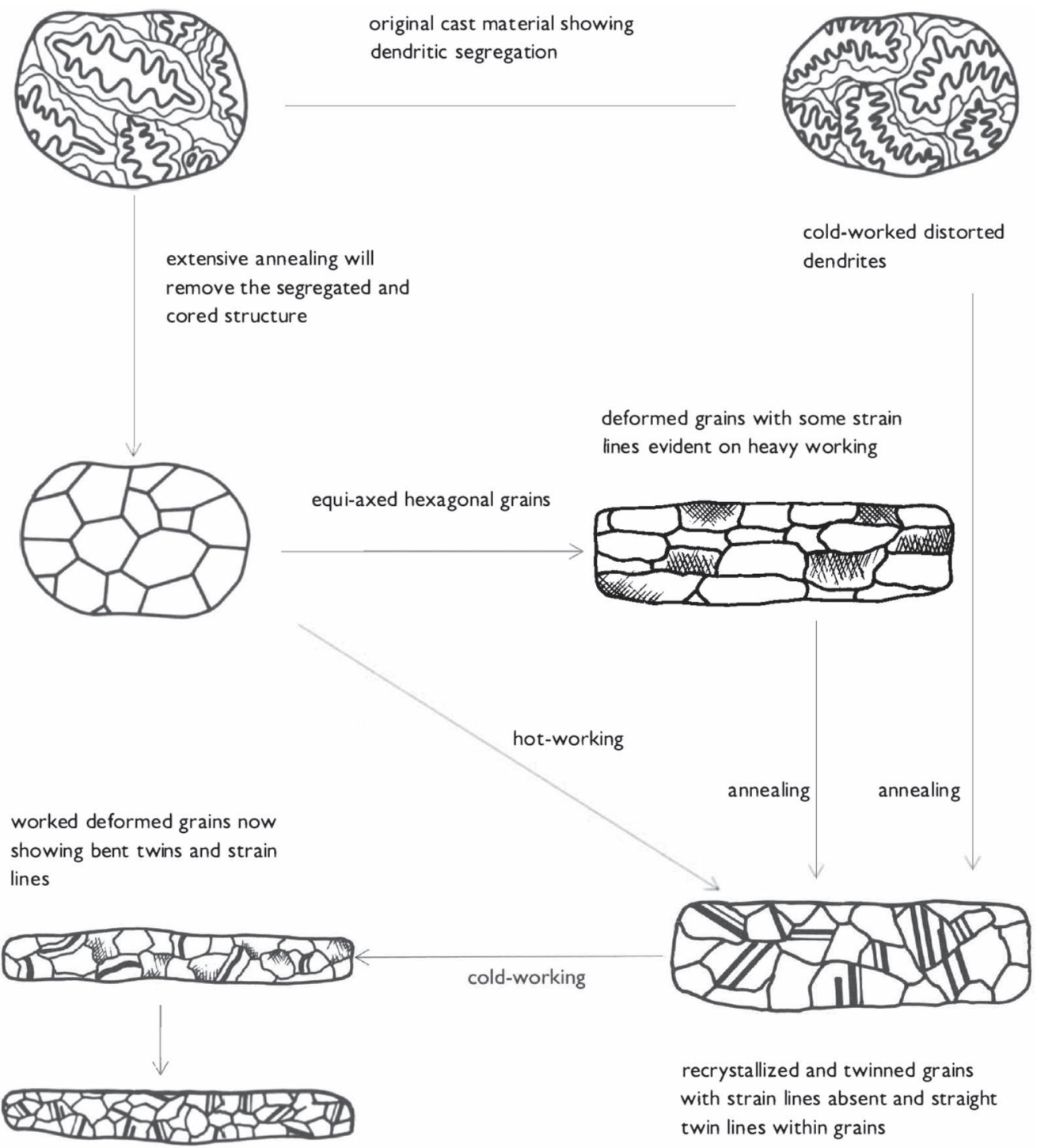

recrystallized and twinned grains

with straight twin lines;

grain size usually smaller.

Figure 1: (from ref. 11) relationship between microstructure (cast and worked) in FCC metals used in antiquity. Figure 1: (d'après réf. 11) relation entre microstructures coulées et travaillées en métal FCC utilisés dans l'Antiquité.
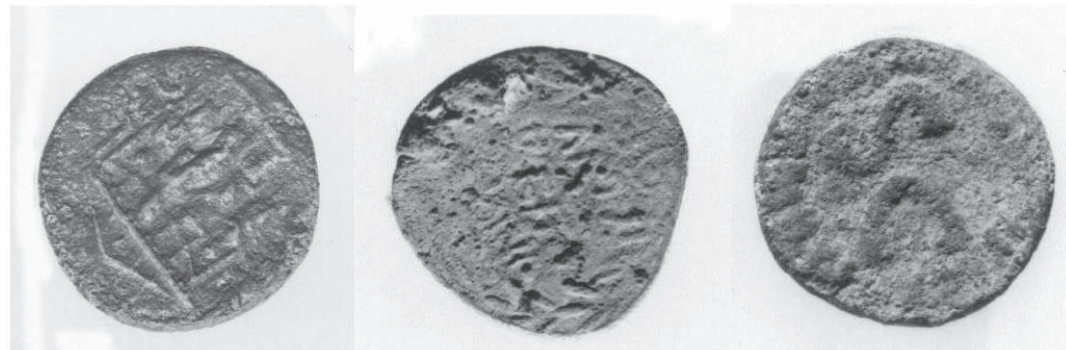

Figure 2: photos of the coins SC, D22 and A10.

Figure 2 : clichés des monnaies SC, D22 et A10. 


\begin{tabular}{|c|c|c|c|c|c|c|c|c|c|}
\hline & Area of production & $\mathrm{Cu} \%$ & $\mathrm{Zn} \%$ & $\mathrm{Ni} \%$ & $\mathrm{Fe} \%$ & $\mathrm{~Pb} \%$ & Sn $\%$ & Alloy & $\begin{array}{l}\text { Hardness } \\
\text { HV } 0.2\end{array}$ \\
\hline A A & As $\mathrm{R}$ & Bal & - & $<0.01$ & 0.005 & 0.1 & 0.15 & $\mathrm{Cu}$ & $120+-4$ \\
\hline A B & As $\mathrm{R}$ & $\mathrm{Bal}$ & - & 0.23 & - & 0.9 & - & $\mathrm{Cu}$ & $60+-1$ \\
\hline $\mathrm{AD}$ & As $\mathrm{R}$ & Bal & - & 0.01 & $<0.1$ & $<0.1$ & $<0.1$ & $\mathrm{Cu}$ & $102+-6$ \\
\hline A I & As Nicopolis p & $\mathrm{Bal}$ & $<0.1$ & $<0.01$ & $<0.1$ & 0.8 & $<0.1$ & $\mathrm{Cu}$ & $123+-1$ \\
\hline A 1 & As a & Bal & $<0.1$ & $<0.01$ & $<0.1$ & 1.0 & $<0.1$ & $\mathrm{Cu}$ & $60+-2$ \\
\hline A16 & As a & $\mathrm{Bal}$ & $<0.01$ & $<0.01$ & $<0.01$ & 1.0 & - & $\mathrm{Cu}$ & $57+-2$ \\
\hline A 4 & As a- & Bal & $<0.1$ & 0.06 & - & 29.7 & 3.0 & $\mathrm{Cu}-\mathrm{Pb}-\mathrm{Sn}$ & $60+-3$ \\
\hline A 10 & As a- & $\mathrm{Bal}$ & 1.4 & 0.6 & 0.01 & 16.4 & 6 & $\mathrm{Cu}-\mathrm{Pb}-\mathrm{Sn}$ & $67+-1$ \\
\hline A13 & As a- & $\mathrm{Bal}$ & 0.6 & 0.02 & - & 7.0 & - & $\mathrm{Cu}-\mathrm{Pb}$ & $55+-1$ \\
\hline A15 & $\mathrm{Aa}-$ & Bal & $<0.01$ & $<0.01$ & 0.01 & 12.1 & 2.9 & $\mathrm{Cu}-\mathrm{Pb}-\mathrm{Sn}$ & $62-+3$ \\
\hline A17 & As a- & Bal & 0.08 & $<0.01$ & 0.01 & 7.64 & $<0.1$ & $\mathrm{Cu}-\mathrm{Pb}$ & $82+-6$ \\
\hline$\underline{\mathrm{SC}}$ & Sest R & Bal & 20.6 & 0.06 & 0.4 & $<0.1$ & $<0.1$ & brass & $66+-1$ \\
\hline$\underline{\mathrm{SO}}$ & Sest a+ & $\mathrm{Bal}$ & 17,9 & 0.05 & 0.3 & 5.5 & - & brass & $90-+5$ \\
\hline D3 & Dup a+ & $\mathrm{Bal}$ & 17.1 & $<0.01$ & - & 0.9 & - & brass & $185+-3$ \\
\hline$\underline{\mathrm{D} 5}$ & Dup a+ & Bal & 23.7 & 0.03 & $<0.1$ & 0.1 & $<0.1$ & brass & $128+-10$ \\
\hline D6 & Dup a+ & $\mathrm{Bal}$ & 19.4 & $<0.01$ & - & 1.5 & 0.2 & brass & $93+-4$ \\
\hline D20 & Dup a- & Bal & 22 & 0.04 & - & 0.3 & - & brass & $74+-2$ \\
\hline $\mathrm{D} 22$ & Dup a- & Bal & 19.3 & 0.08 & 0.2 & 0.4 & $<0.1$ & brass & $90+-4$ \\
\hline
\end{tabular}

Table 1: chemical composition and hardness of the coins.

Tableau 1 : composition chimique et dureté des monnaies.

To calculate the Sn concentration, the precipitated solid, $\mathrm{SnO} 2$ was dried and weighed, as the older ICP spectrometer was not too sensitive to $S$.

The usual metallographic techniques (cutting, embedding, polishing and etching) have been employed to prepare the cross sections for microstructural examination. The observation was performed by means of optical and electron microscopy (SEM)

The SEM (Stereoscan 440 Leica) equipped with EDS (Falcon Fei, HTW) was used to investigate the grain microstructure, twins, slip lines, corrosion layers and inclusions (when present). The chemical composition was determined with EDS by ZAF correction.

EDXRF and ED's data were used as qualitative data for the ICP measurements.

The hardness has been measured at the core of each cross section with a Vickers micro indenter, with a $0.2 \mathrm{~kg}$ load.

\section{RESULTS AND DISCUSSION}

\section{Chemical composition}

Table 1 reports the chemical composition, obtained by ICP-OES analysis and gravimetry for $\mathrm{Sn}$. The data are given, as usual, on the basis of repeated tests for each element. The second column reports the area of production: the coins produced in Rome are indicated with $\mathrm{R}$, the others with a (auxiliary) and $\mathrm{p}$ (provincial), with the following comments: $\mathrm{a}^{-}=$very stylistically and morphologically degraded auxiliary production,

a+ = good auxiliary production, similar to central production

$\mathrm{a}=$ normal auxiliary production

The last column reports the hardness measured at core (HV0.2)

On the basis of the chemical compositions, reported in table 1, the coins can be divided in three main groups: pure $\mathrm{Cu}$ coins (samples $\mathrm{AA}, \mathrm{AB}, \mathrm{AD}, \mathrm{AI}, \mathrm{A1}, \mathrm{A} 16$ ) named as group 1, Cu-Pb-Sn coins (A4, A10, A13, A15, A17) named 
as group 2, and brass or orichalcum coins (samples SC, SO, D3, D5, D6, D20, D22) named as group 3. All the coins belonging to group 1 are Asses, sample $\mathrm{AD}$ is a Rome issue, while the others are auxiliary or provincial issues.

In group 1 , traces of $\mathrm{Ni}, \mathrm{Fe}, \mathrm{Zn}, \mathrm{Sn}$ and $\mathrm{Pb}$ have been measured and small amounts of $\mathrm{Cu}$ oxides and sulphides have been detected with SEM-EDS. The low amount of $\mathrm{Pb}, \mathrm{Zn}, \mathrm{Ni}, \mathrm{Fe}$ and $\mathrm{Sn}$ cannot be considered intentional additions, but just related to raw materials and/or to the refining process (14). Lead is not soluble in solid $\mathrm{Cu}$ and it is dispersed as small globules. $\mathrm{Pb}$ content less than 3\% has no effect on the alloy properties.

All the coins have a recrystallized structure; the grains are not oriented with a size ranging from 10 to 80 microns. The hardness values are in the range $60-120 \mathrm{HV}$, and are typical of the cold worked and annealed $\mathrm{Cu}$ alloys with different grain sizes (11).

The microstructures and hardness might not be related to the slightly different composition but only to different thermal and time parameters during annealing and cold working process.

At present, the reported data suggest that pure $\mathrm{Cu}$ Rome issues and pure $\mathrm{Cu}$ auxiliary issues are very similar, as far as the chemical composition and the microstructure.

The specimens A4, A10, A13, A15 and A17, are $\mathrm{Cu}-\mathrm{Pb}$ or $\mathrm{Cu}-\mathrm{Pb}-\mathrm{Sn}$ coins and form group 2 . All the coins of this group are auxiliary Asses, and belong to a provincial deepdegraded coinage.

The $\mathrm{Sn}$ content is less than $5 \%$, while $\mathrm{Pb}$ is in the range $8-30 \%$. The common feature to all the coins is the dendritic structure, typical of cast specimens. This is not surprising because alloys with high $\mathrm{Pb}$ content are very castable but they are not suitable for mechanical working. These coins have been produced by casting the liquid alloy into a preimpressed die. The hardness is in the range from 50 to 80 $\mathrm{HV}$, as expected from the composition and microstructure.

The use of a Cu-Sn-Pb alloy instead of $\mathrm{Cu}-\mathrm{Sn}$ or pure $\mathrm{Cu}$ for Asses production could be explained by as follows:

1. As the $\mathrm{Cu} / \mathrm{Sn}$ ratio is 6.8 and is typical of a cold working bronze, that suggests a scarcity of suitable alloys and the recycling of bronze scraps followed by a $\mathrm{Pb}$ addition, in order to get a more castable alloy.

2. To increase coin production by the use of a Cu-Sn-Pb alloy with well-known casting properties.

The specimens of group 3, formed by 2 Sestertii (samples SC, SO) and 5 Dupondii (samples D3, D5, D6, D20 and D22) have the typical composition of the orichalcum (brass), with $\mathrm{Zn}$ the range $17-24 \%$. These compositions are typical for cold working brass (12). All the coins have a recrystallized structure, with polygonal grains, slip lines and twins. These features confirm the cold working and annealing processes of the blanks before striking.

The grain size varies from 50 to 100 microns and the hardness from 70 to $180 \mathrm{HV}$, typical of the cold worked and annealed brass (11). The wide range of grain size and hardness can be related to different times and temperature conditions during working and annealing, as already explained for the $\mathrm{Cu}$ coins. The low $\mathrm{Zn}$ content and the shape (petal-like) of some coins suggest also that they could have been obtained by remelting or by cutting a Sestertius. The process of remelting a Sestertius may induce a $\mathrm{Zn}$ loss, without an evident change in surface colour, so the obtained Dupondii have been progressively $\mathrm{Zn}$ debased.

The coin SO has a $\mathrm{Pb}$ content about $5 \%$, this amount could indicate a deliberate $\mathrm{Pb}$ addition to a $\mathrm{Cu}-\mathrm{Zn}$ alloy in order to save $\mathrm{Zn}$ without modifying the colour or during a $\mathrm{Cu}-\mathrm{Zn}$ reuse in order to compensate the $\mathrm{Zn}$ loss.

The problem of controlling the $\mathrm{Zn}$ content in historical brass manufacture is well known (13). Before the developing of metallic zinc technology, the cementation process was the only one method of brass production and the upper limit to the amount of $\mathrm{Zn}$ is approximately $28 \%$, depending on thermodynamic parameters. The final content of $\mathrm{Zn}$ depends not only on the $\mathrm{Cu}, \mathrm{ZnO}$ and Carbon content but also the zinc loss must be taken into account (13).

The volatility of $\mathrm{Zn}$ could also affect the final composition of coins produced by re-melting old coins. As the colour and weight of the coin were fixed, the addition of $\mathrm{Pb}$ could be a solution to compensate the $\mathrm{Zn}$ loss or to facilitate brass manufacture.

\section{Microstructure OF SOME REPRESENTATIVE COINS}

\section{Group 1: Regular and auxiliary asses}

Coin AD: it is a regular Tiberian as of the series in the name of Divus Augustus Pater. The morphological aspect (weight, diameter and stylistic view) confirm its regular Rome central mint origin. Figs. 3 (area under the impressed surface) and 4 (core) show the micrographs. The core grains are coarse, partially oriented, with a mean size of $70+-5$ microns and a core hardness of $102+-6 \mathrm{HV}$. The orientation may be due to the annealing process that was not able to cause a complete recrystallization. Slip lines and more deformed grains are present underneath the impressed design, confirming obviously no further annealing after striking. 


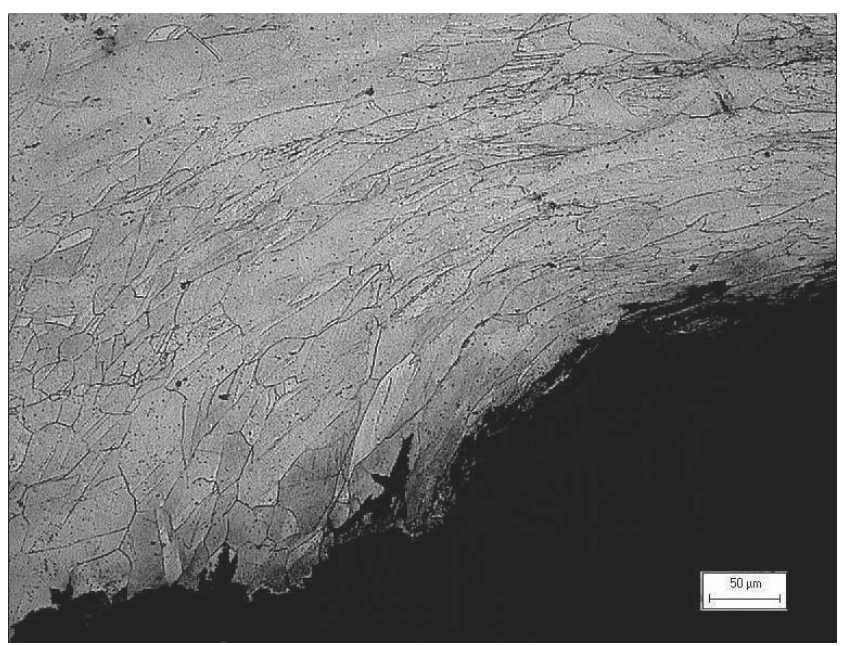

Figure 3: OM micrograph of surface of coin AD (As). Figure 3: Micrographe OM de la surface de la monnaie $A D(A s)$.

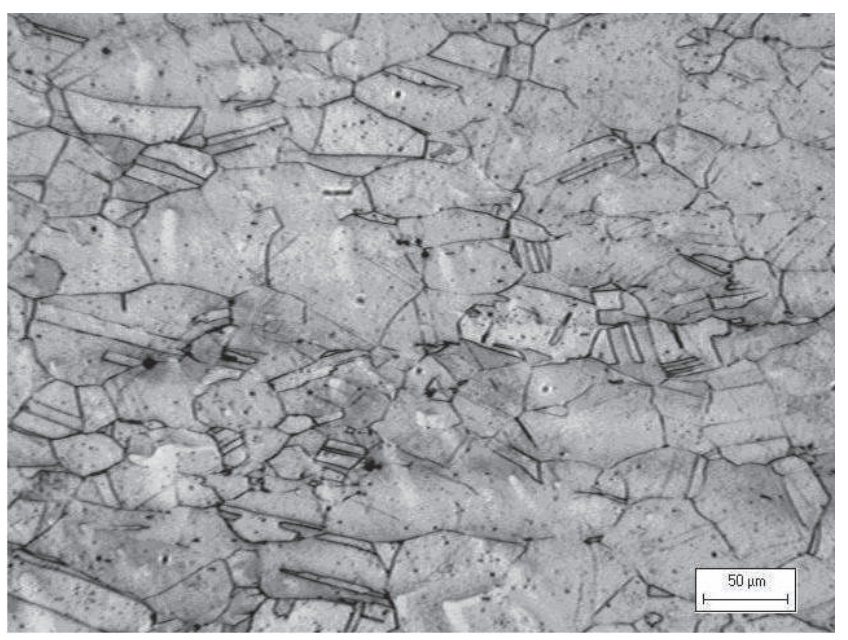

Figure 4: OM micrograph of core of coin AD (As).

Figure 4: Micrographe OM du cour de la monnaie $A D(A s)$.

Coin AI is an auxiliary As, issued by the Thracian mint of Philippopolis in name of Antoninus Pius. It is the lowest nominal of the series and shows the morphological characters of the usual provincial production of the mints of the Moesian-Thracian region in the middle Roman Imperial time.

Figures 5 and 6 report its micrographs. This coin has a very fine recrystallized structure; the grains are not oriented with a mean size less than 5 microns. The core hardness is $123+-1 \mathrm{HV}$. A few slip lines are present underneath the impressed design, while twins and some slip lines (fig. 6) are in the inner part. The fine grain size and presence of twins suggest that the coin was completely annealed after the mechanical working for a short time or at low temperature as the recrystallization process was completed without grain growth. The presence of slip lines suggests that the coin was not annealed after the striking, as obviously expected. It is confirmed by the presence of some cracks, probably due to the hardening caused by the striking process.

Coin AI (auxiliary As) has the same chemical composition of coin AA (regular as), but the grain size is much finer and the hardness is higher. This data could be explained by the difficult in standardizing the process parameters (time and temperature of annealing, \% of reduction, cooling rate) from casting to striking.

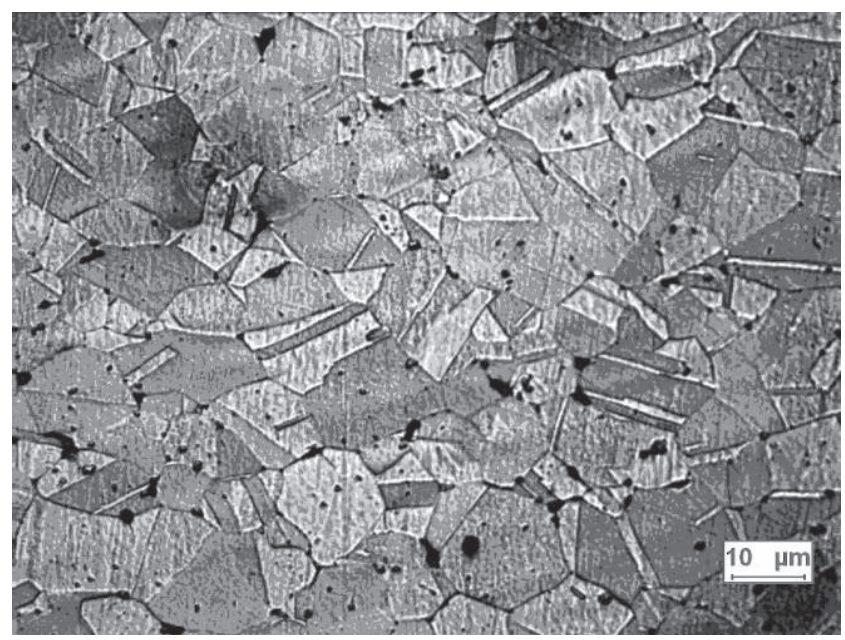

Figure 5: OM micrograph of coin AI (As).

Figure 5: Micrographe OM de la monnaie AI (As).

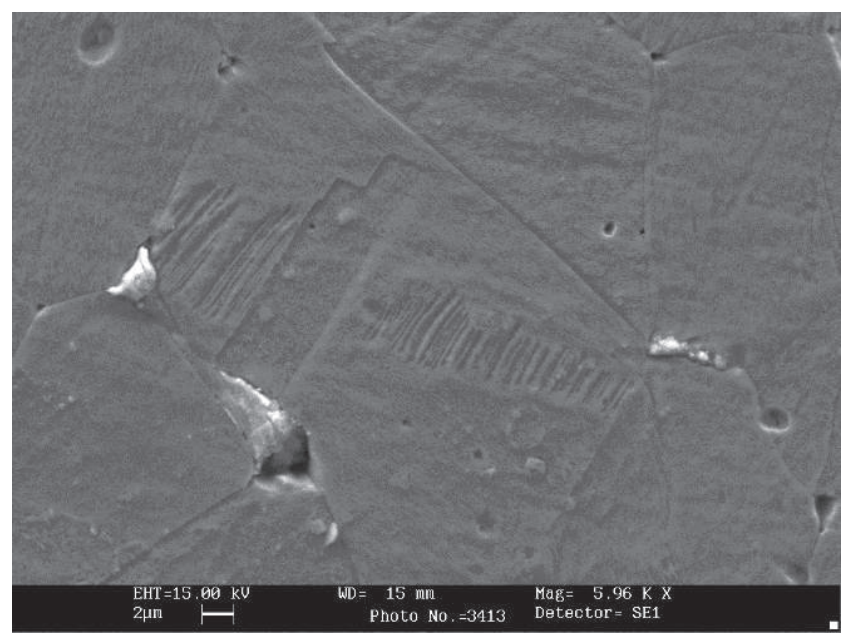

Figure 6: SEM-BSE micrograph of AI with slip lines Figure 6 : Micrographe SEM-BSE de AI avec lignes glissantes ?????? 


\section{Group 2}

Specimen A10 is a Tresviral Augustean As and belongs to a provincial deep-degraded coinage. It shows a quite illegible surface and the main morphological aspects, principally the weight $(6,72 \mathrm{~g})$, and the diameter, ca. $24,5 \mathrm{~mm}$, are in no way comparable with the Roman central standards.

In fig. 7 its OM micrograph is reported, showing a typical dendritic structure, with porosities and $\mathrm{Pb}$ globules in the $\mathrm{Cu}-\mathrm{Sn}$ solid solution. It confirms that the coin was obtained only by casting, without mechanical working instead of by striking, as the coins of the central mint of Rome. The unexpected $\mathrm{Zn}(1.5 \%)$ content in this coin is probably due the remelting of some $\mathrm{Zn}$ containing scraps during the alloy production.

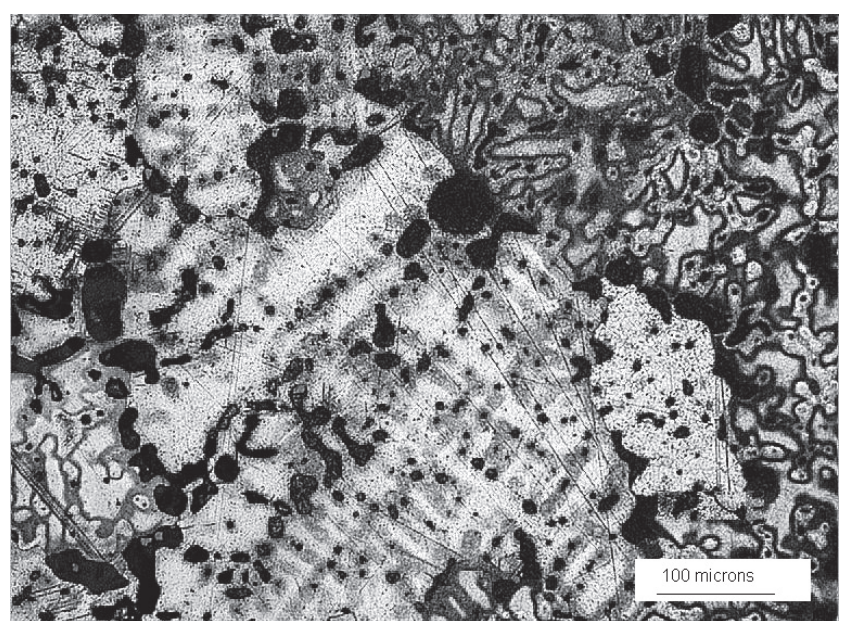

Figure 7: OM micrographs of coin A10 (As).

Figure 7: Micrographes OM de la monnaie A10 (As).

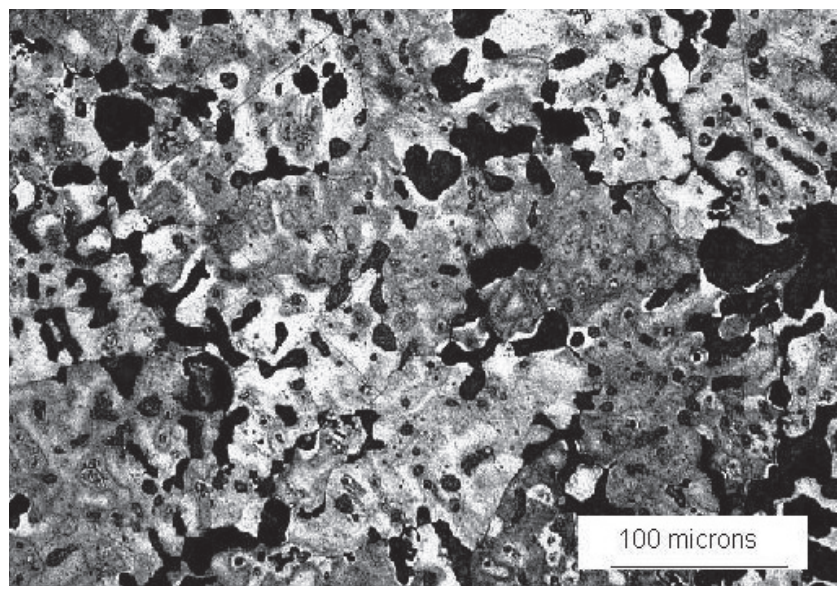

Figure 8: OM micrograph of coin A15 (As).

Figure 8: Micrographe OM de la monnaie A15 (As).

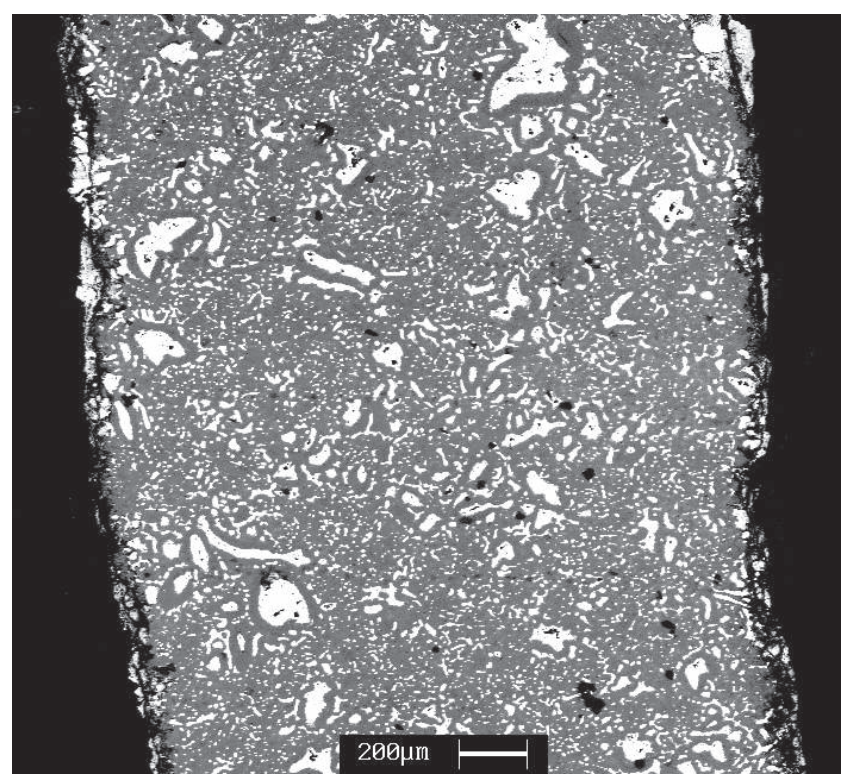

Figure 9: SEM-BSE micrograph of coin A15(As).

Figure 9: Micrographe SEM-BSE de la monnaie A15 (As).

The specimen A15 is a Tresviral Augustan As and belongs to a provincial degraded coinage, but the main morphological aspects are almost regular: the weight, $8,52 \mathrm{~g}$, is not so different from the average Roman central standard $(10,91 \mathrm{~g})$, and the diameter, ca. $26 \mathrm{~mm}$, is similar to the Roman ones. Just the surface of the specimen denotes the usual aspect of the cast coins. Fig 8 reports its OM micrograph with the dendritic morphology, a lot of porosities and Pb globules. In the SEMBSE micrograph (fig.10) the $\mathrm{Pb}$ (white areas) is more evident.

The examination of coins A10 and A15 confirms the numismatic hypothesis, based on visual inspection, that they have been produced by casting.

\section{Group 3: Sestertius and Dupondii}

Coin SC is a regular Sestertius struck by the Roman mint in name of Caligula: all the morphological aspects of this coin i.e. diameter and weight, show the high level of engraving style and the quality of technological knowledge of the Roman central mint operators.

The $\mathrm{Zn}$ content $(20 \%)$ is close to the standard orichalcum composition $(13,14)$ for the Sestertius $(\mathrm{Zn}=20-25 \%)$. Fig. 10 reports the micrograph of the Alpha-brass taken at the core of the coin C. The regular core grains with twins are visible, with a few slip lines underneath the design, confirming that the coin was annealed after the work hardening, just before striking.

In fig. 11 the SEM-BSE micrograph with a long-shaped inclusion is reported. The EDS analysis confirms the pre- 
sence of $\mathrm{S}$ and $\mathrm{Cu}$, so it can considered as a $\mathrm{Cu}$ sulphide, as typical in ancient alloys.

The value of mean grain size is $50-100$ microns and hardness value is about $66 \mathrm{HV}$.

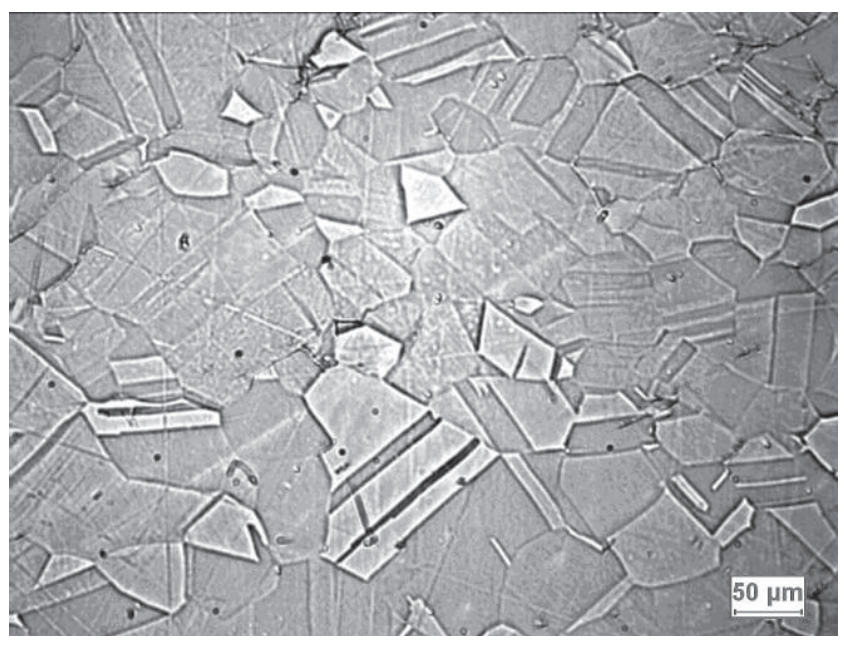

Figure 10: OM micrograph of coin SC.

Figure 10: Micrographe OM de la monnaie SC.

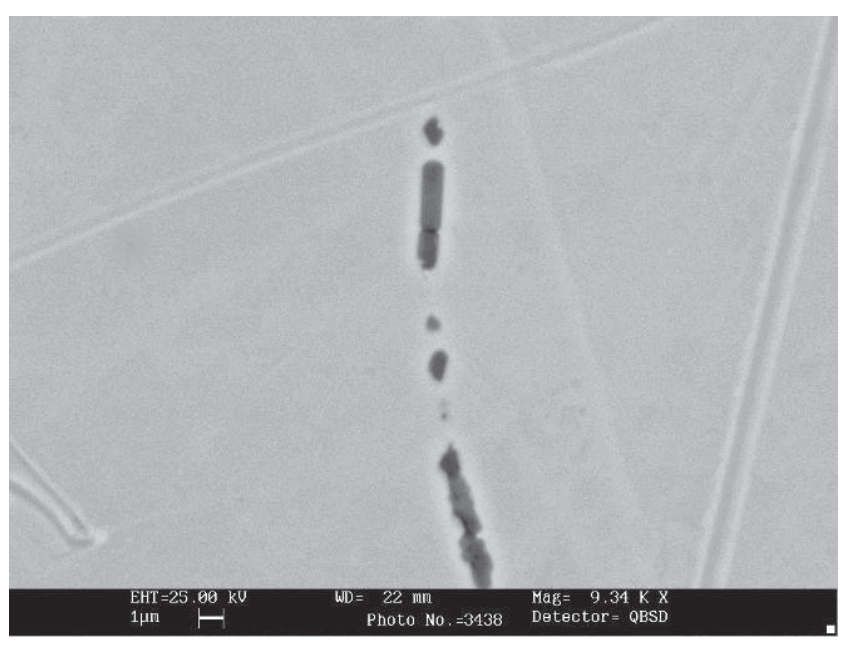

Figure 11: SEM-BSE micrograph with a Sulphide inclusion. Figure 11 : Micrographe SEM-BSE avec une inclusion de sulphide.

\section{Coin D22}

It is a Tresviral Augustean Dupondius; it belongs to an auxiliary coinage and shows a general degradation of the main morphological aspects.

Its OM micrograph is reported in fig. 12. There are a few slip lines and the grains underneath the surface are only partially deformed. The core grain size is about 70-80 microns with a lot of twins. The hardness value and grain size suggest that coin D 22 was annealed at a temperature intermediate between the $\mathrm{D} 5$ and $\mathrm{SC}$ ones.

The crack that crosses the specimen underneath the surface (see Fig. 12) and the irregular petal-like shape suggest that this coin could have been obtained by cutting and hammering a regular Sestertius (type SC).

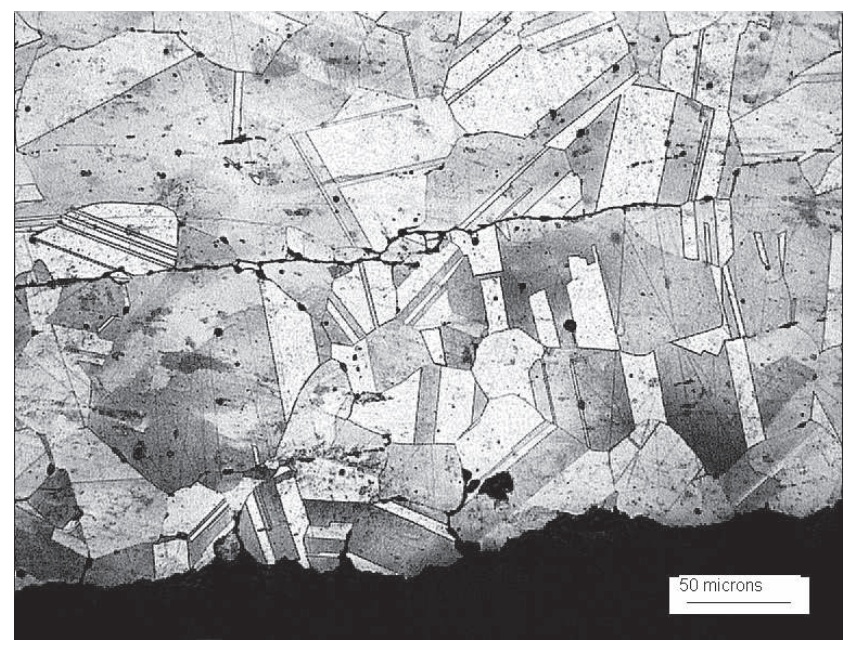

Figure 12: OM micrograph of coin D22.

Figure 12 : Micrographe OM de la monnaie D22.

\section{Coin D5}

It is a Tresviral Augustean Dupondius struck in an auxiliary mint. Coin. D5 denotes a general good quality of the level of production, apart from the stylistic aspect which is lightly less than the usual one, perhaps the specimen belongs to a "decadent" coining.

Specimen D5 has $\mathrm{Zn}$ content about $24 \%$, similar to coin SC (Alpha-brass). Fig. 13 reports its SEM-BSE micrograph taken under the impressed design. The strong and diffused slip lines underneath the surface are evidenced by the corrosion growing along them.

This hardened structure, with the grains strongly deformed, is due to the image impressing by high cold working. The core grains are more regular and less deformed than in $\mathrm{SC}$, confirming that the coin was annealed after the work hardening, without annealing after the coinage. The mean grain size is about 60 microns. 


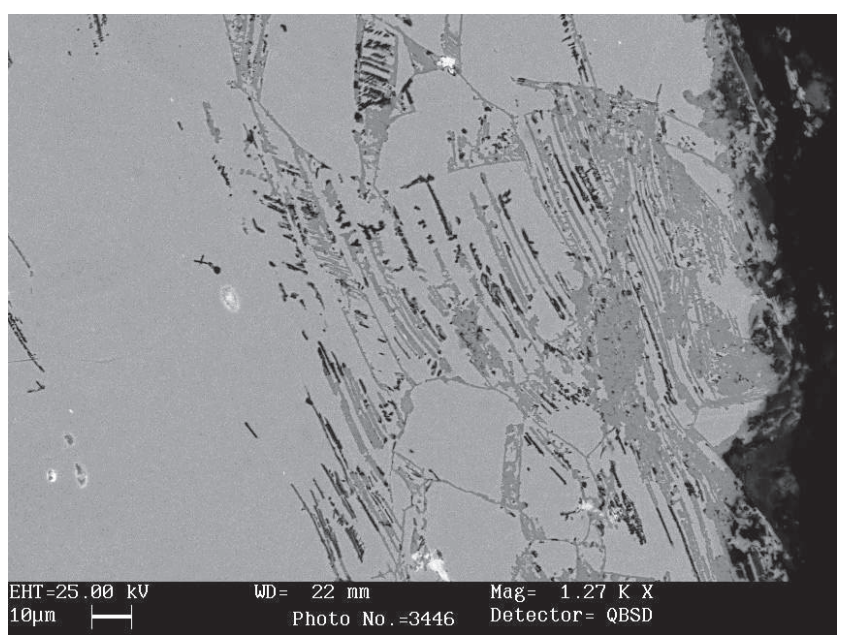

Figure 13: SEM micrograph of coin D5.

Figure 13 : Micrographe SEM de la monnaie D5.

\section{ConClusions}

The metallurgical and chemical investigation on Roman Imperial $\mathrm{Cu}$-base coins allows concluding that:

The coinage process may be divided in 4 steps (11): production and casting of an alloy, production of the blanks, cold-working and annealing of the blanks to the final coin dimension and design impression by die striking.

The numismatic hypotheses based on visual and stylistic examinations have been confirmed both for alloy composition (quite pure $\mathrm{Cu}$, brass and $\mathrm{Cu}-\mathrm{Pb}$ ) and coinage process (casting and striking)

The microstructures of the examined coins suggest that the mechanical working and annealing processes of pure $\mathrm{Cu}$ and brass coins could be performed with different parameters.

The microstructure (grain size, slip lines, twins) and hardness values of the $\mathrm{Cu}$ and brass struck coins cannot be related to the chemical composition, but suggests different temperatures of working and striking process. It is known that the process of annealing can be divided in recovery, recrystallization and grain growth, with several variables (amount of initial deformation, temperature, time, initial grain size, composition) influencing the recrystallization behaviour (15). As the recrystallization temperature depends on the indicated variables, it is not a fixed temperature in the sense of a melting temperature. Also the grain growth is strongly temperature dependent, and a grain-coarsening region will be soon reached in which the grains increase very rapidly. The microstructure of the core is mainly determined by the parameters of the initial cold working process employed on the cast blanks. The microstructure of the areas underneath the impressed design is mainly determined by the final cold working process, whose effect partly depends also on the initial microstructure.

The regular Augustean As is composed by almost pure $\mathrm{Cu}$, with a fine grain structure, whereas a part of the "auxiliary" samples has a $\mathrm{Cu}$ content in the range 70-90\%, with different $\mathrm{Pb}$ and $\mathrm{Sn}$ amounts and dendritic structure. The regular Dupondius is brass made, while the "auxiliary" samples have sometimes a lower $\mathrm{Zn}$ content, with lower weight and an unusual shape. The coins with a low $\mathrm{Zn}$ content could be obtained by remelting some Sestertii. It is known that during the remelting of brass it is possible to have a $\mathrm{Zn}$ loss. The coins with irregular shape (petal-like morphology) probably have been obtained by cutting regular Sestertii and by hammering the pieces. This process allows both alloy composition and colour to be maintained.

On the contrary the auxiliary Asses (former Limesfalsa) show a progressive degradation in composition $(\mathrm{Pb}-\mathrm{Sn}$ addition), morphology and weight.

This study could confirm the theory of a partly de-centralized issuing of the base metal coins, and the hypothesis that the primary brass production occurred under the control of the central mint. The Caley's zinc decline, as discussed by Dungworth (16) can be neither supported nor rejected by our results due to the limited number of samples analysed herein. The question of $\mathrm{Pb}-\mathrm{Sn}$ content (16) is more complex and cannot be discussed on the basis of chemical composition data.

Only the combination of chemical analysis with metallurgical investigation on cross sections results in a complete description of the coin.

\section{References}

1) Sutherland, H. V., 1984. Roman Imperial Coinage, London, 94.

2) Besombes, P.-A., 2000. Revue Numismatique, 26, 79.

3) Besombes, P.-A., 2003. Le Trésor de Saint Léonard, Trésors Monetaires, XVI.

4) Martini, R., 2001. La Collezione Veronelli, Glaux S.S.II, Ed. Ennerre.

5) Martini, R., 2002. Collezioni Numismatiche 2, Ed. Ennerre.

6) Crawford, M. H., 1974. Roman Republican Coinage, Cambridge.

7) Bouyon, B., Depeyrot, G., Desnier, J.-L., 2000. Systèmes et technologie des monnaies de bronze, coll. "Moneta; 19 ", Wetteren. 
8) Carter, G. F., 1988. Zinc content of Neronian semisses and quadrantes and the relative value of copper and zinc in the coins of Nero, ANSMN, 33.

9) Cowell, M., Pointing, M., 2000. British Museum Analyses, in Metallanalytische Untersuchungen am Muenzen der Romischen Republik, Gebr. Mann Verlag-Berlin, 49.

10) La Niece, S., 1988. Metallography in Numismatics, in Metallurgy in Numismatic, ed. W. A. Oddy and M. R. Cowell, RNS, Special publication 30, London (1998), 114.

11) Sсотт, D. A., 1991. Metallography and microstructure of ancient and historic metals, Ed. The Getty Conservation Institute.
12) Newbury B. D., Notis M., Newbury D. E., 2005. Revisiting the zinc composition limit of cementation brass, HMS, 39, 2.

13) Caley, E., 1964. Orichalcum and related ancient alloys, The Am. Num. Soc.

14) Tylecote, R. F., 1992. A History of Metallurgy, The Inst. of Materials, 58.

15) Dieter, 1987. Mechanical Metallurgy, McGrawHill, 234.

16) Dungworth, D., 1996. Caley "Zinc decline” reconsidered, The Numismatic Chronicle, 238, 156. 